Research Report No. 5/2010

\title{
Creating a Working Vocabulary of Sovereignty: Language at the International Court of Justice
}

D. Alison von Rosenvinge

Follow this and additional works at: http:// digitalcommons.osgoode.yorku.ca/clpe

\section{Recommended Citation}

von Rosenvinge, D. Alison, "Creating a Working Vocabulary of Sovereignty: Language at the International Court of Justice" (2010). Comparative Research in Law \& Political Economy. Research Paper No. 5/2010.

http://digitalcommons.osgoode.yorku.ca/clpe/74 


\title{
OSGOODE
}

OSGOODE HALL LAW SCHOOL

YOR K UN I VERSITY

\section{OSGOODE HALL LAW SCHOOL}

Comparative Research in Law \& Political Economy

\author{
RESEARCH PAPER SERIES
}

Research Paper No. 05/2010

\section{Creating a Working Vocabulary of Sovereignty: LANGUAGE AT THE INTERNATIONAL COURT OF JUSTICE}

D. Alison von Rosenvinge

\section{Editors:}

Peer Zumbansen (Osgoode Hall Law School, Toronto, Director, Comparative Research in Law and Political Economy)

John W. Cioffi (University of California at Riverside)

Lisa Philipps (Osgoode Hall Law School, Associate Dean Research)

Nassim Nasser, Ahmed Hassan (Osgoode Hall Law School, Toronto, Production Editors) 
CLPE Research Paper 05/2010

Vol. 06 No. 2 (2010)

\title{
D. Alison von Rosenvinge
}

\section{Creating a Working Vocabulary of Sovereignty: Language at the International Court of Justice}

\begin{abstract}
What is sovereignty?" If there are questions international legal and political scholars ought to be able to answer, this is certainly one. State sovereignty is arguably the basis of all political and legal international relations. And, yet, what it means remains elusive. As we discuss whether we are witnessing the demise of the Westphalian system, it is critical to understand state sovereignty today.
\end{abstract}

Despite the resurgence in sovereignty scholarship, there has been little empirical work done that combines political and legal theory. This project addresses that gap in the current literature between political science and international legal research by providing an empirical study of how sovereignty is conceptualized in international legal discourse. The theoretical basis for this paper is largely informed by international relations theory of binding states and the variability of sovereignty. The methodological approach is legal case analysis. Because sovereignty is such a slippery concept, the question of how to study it is tricky. This paper will follow Jens Bartelson's approach and avoid the direct question "what is sovereignty?" and instead ask the question "how do we discuss sovereignty?" The project provides an analysis of advisory opinions and contentious cases before the International Court of Justice over the last fifteen years.

The results of the research contribute to a general understanding of contemporary sovereignty in two main ways: Firstly, the study provides a framework of "ideal types" which suggests that contemporary notions of sovereignty fall into three main categories: (1) as the final and supreme power of the state requiring no justification ("The Prince"), (2) as a supreme power justified by the state's ability to protect its citizens from both internal and external threats ("The Protector"), and (3) as a privilege granted by citizens of the state and the international community in return for accepting certain norms and fulfilling certain responsibilities ("The Citizen"). Secondly, the paper suggests that with a viable working vocabulary, legal and political scholars can then address questions concerning how the legal discussion of sovereignty interacts with international relations structure.

Keywords: Law, International Law, Sovereignty, International court of justice

JEL Classification: K33 


\section{Alison von Rosenvinge \\ Research Scholar, New York Law School}

Ph.D. and J.D. University of Pennsylvania; alison.von.rosenvinge@gmail.com. 


\title{
Creating a Working Vocabulary of Sovereignty: Language at the International Court of Justice
}

\author{
D. Alison von Rosenvinge* \\ Sovereignty is not obsolete, but it needs to be re-examined carefully. ${ }^{1}$
}

\section{INTRODUCTION}

The problem with sovereignty is that its meaning encompasses not only ideas that are different but concepts that are in direct tension with each other, if not actually mutually exclusive. Sovereignty is both the sphere of a state's liberty without an independent normative status as well as the description of the state endowed with certain rights by a prior normative code. ${ }^{2}$ Martti Koskenniemi has described at length "[t]he ambiguity about the modern doctrine of sovereignty follows this paradox." ${ }^{3}$ At one extreme is the sovereignty of Carl Schmitt, with his emphasis on the political power to decide the exception to normative obligations and, at the other extreme, the sovereignty of Hans Kelsen, with his emphasis on the state as deriving its authority from complying with certain basic norms. ${ }^{4}$ As a consequence, the modern conceptualization of sovereignty is in flux, alternating between two extremes.

Between these two extremes, we can agree that state sovereignty is about power and law. ${ }^{5}$ We use the term itself to describe both the political and legal status of a state. In the political realm, state leaders rely on sovereignty to justify action to their own people and to the global community. In the legal realm, international organizations use state sovereignty as a threat and a promise to obligate state leaders to conform to rules and norms. Despite the fact that the term is used to mean so many things that it is almost meaningless, we come back to it, because

\footnotetext{
* Research Scholar, New York Law School; Ph.D. and J.D. University of Pennsylvania; alison.von.rosenvinge@gmail.com.

${ }^{1}$ Thomas M. Franck, The Shifting Allocation of Authority in International Law: Considering Sovereignty, Supremacy and Subsidiarity 21 (Tomer Broude and Yuval Shany eds., 2008).

${ }^{2}$ Martti Koskenniemi, From Apology to Utopia: The Structure of International Legal Argument 224 (2005).

${ }^{3}$ Id. at 225 .

${ }^{4}$ Id. at 226.

${ }^{5}$ Stephen D. Krasner, Sovereignty: Organized Hypocrisy 3 (1999).
} 
there is something about sovereignty that has not been replaced by alternative political and legal systems. For now, the sovereign state persists as the basis of political and legal systems. ${ }^{6}$

If we can agree that state sovereignty remains a vital part of international relations and international law in the twenty-first century, we should also be able to admit that we need a working vocabulary to discuss and analyze what it is. There may have been a time when the classic conceptualization of sovereignty in the tradition of Bodin or Hobbes-based on the ideal that leaders of discrete territorial entities exclude all external actors from domestic government decision making-was a satisfactory description, but in a world where both the United Sates and Fiji are sovereign, we need a more nuanced vocabulary today. ${ }^{7}$

The recent resurgence of sovereignty scholarship reflects a shared sense that no matter how overused and vague the term sovereignty is, it remains a critical part of international legal and political relations. Our world is highly interdependent (as we know from crises in our capital markets, environment, technology). ${ }^{8}$ One could be forgiven for thinking that the most important matters span all national boundaries, and yet the sovereign state remains the basis for all international relations. Yet, as Jens Bartelson has pointed out, "modern political science often testifies to its own inability when it tries to come to terms with the concept and reality of sovereignty; it is as if we cannot do to our contemporaneity what Bodin, Hobbes and Rousseau did to theirs." ${ }^{\prime 9}$

We have not "come to terms" with sovereignty because we haven't tried, but because we have not approached it as both the legal and political subject that it is. Contemporary universities divide the study of law and politics into different departments (even entirely different schools), leaving those subjects that span both disciplines inadequately studied. Political scientists may be too skeptical that international law has any weight in international relations, and legal scholars may not be skeptical enough. There must be some middle ground for studying sovereignty from both the perspective of politics and law. Jean Bodin was both a jurist and a political philosopher, as was Carl Schmitt, Alexander Hamilton and John Jay. In this project, I want to begin to re-integrate legal and political theories to study sovereignty. This paper is a modest first step in a larger effort to provide an empirical study of how sovereignty is conceptualized in international legal discourse and what sovereignty means in terms of international relations theories concerning binding states and international political structure.

\footnotetext{
${ }^{6}$ Thomas J. Biersteker and Cynthia Weber, State Sovereignty as Social Construct 3 (1996).

${ }^{7}$ Stephen D. Krasner, Sovereignty: Organized Hypocrisy 20 (1999).

${ }^{8}$ Thomas M. Franck, The Shifting Allocation of Authority in International Law: Considering Sovereignty, Supremacy and Subsidiarity 20-21 (Tomer Broude and Yuval Shany eds., 2008).

${ }^{9}$ Jens Bartelson, A genealogy of sovereignty 1 (1995).
} 
Here I provide an analysis of advisory opinions and contentious cases before the International Court of Justice (the "I.C.J.") in the period since the end of the Cold War.

This research contributes to a general understanding of contemporary sovereignty in two main ways: Firstly, the study demonstrates that sovereignty is not a static characteristic resulting necessarily from certain power configurations, but rather is a bundle of rights and responsibilities that vary according to both domestic and global context. Secondly, the study provides a taxonomy of "ideal types" based on lines of I.C.J. cases that help organize our discussion of sovereignty. The I.C.J. decisions fall into three categories (or ideal types) of sovereignty: (1) The Prince, as the final and supreme power of the state requiring no legal or political justification, (2) The Protector, as state power justified by the state's ability to protect its own citizens from both internal and external threats, and (3) The Citizen, as power granted by citizens and the international community in return for accepting certain norms and fulfilling certain responsibilities.

\section{THE CASES}

\section{A. THe PRINCE}

Sovereignty is not limited either in power, or in function, or in length of time. ${ }^{10}$

The Prince comes as close to the traditional notion of the Westphalian ideal type as any incarnation of sovereignty. This ideal type assumes all power resides in the state because the state exists. In this version of sovereignty, the state does not need to justify, explain or validate its actions or non-actions. There is no higher authority than the state in the international realm. Sovereignty is the power of the state to accept or reject legal obligations.

Jean Bodin and Carl Schmitt best articulate this ideal type of sovereignty. For Schmitt, sovereignty is unlimited, undivided and foremost, a political concept. ${ }^{11}$ Political power controls legal power. In other words, the sovereign state is the source of law and not the reverse.

The existence of the state is undoubted proof of its superiority over the validity of the legal norm. The decision frees itself from all normative ties and becomes in the true sense absolute...The sovereign produces and guarantees the situation in its totality. He has the

\footnotetext{
${ }^{10}$ Jean Bodin, On Sovereignty 3 (Julian H. Franklin ed. and trans.) (1992).

${ }^{11}$ Schmitt, Carl, Political Theology: Four Chapters on the Concept of Sovereignty 5 (George Schwab trans.) (1988).
} 
monopoly over this last decision. Therein resides the essence of the state's sovereignty, which must be juristically defined correctly, not as a monopoly to coerce or rule, but to decide. ${ }^{12}$

The line of cases that embody the Prince share the I.C.J.'s acceptance of the sovereign state as the source of political and legal authority. These cases embody the theme that the sovereign state may at any point accept or reject the legal authority of an international court. Sovereignty is the source of international law and law has power to bind the state only so long as the state consents to be bound. Sovereignty, in this conceptualization, is the ultimate power to decide from which all other power is derived.

\section{Legality of the Use by a State of Nuclear Weapons in ARMed Conflict}

In 1996, the World Health Organization ("WHO") asked the Court to give an advisory opinion on the question "would the use of nuclear weapons by a State in war or other armed conflict be a breach of its obligations under international law including the WHO Constitution?"13 Over 30 states submitted written statements. ${ }^{14}$ Another nine submitted written comments to those statements. ${ }^{15}$ The Court made it clear that its role is to "identify the obligations of States under the rule of law invoked, and assess whether the behaviour in question conforms to those obligations." ${ }^{16}$

The Court determined that it did not have jurisdiction to provide an advisory opinion because the WHO did not have competence to ask the question. The Court explained that international organizations are created by states and are limited to serving the functions for which they were created. ${ }^{17}$ International organizations may only ask the Court for advisory opinions on subjects within the realm for which states had established them. The Court concluded that the WHO did not have the competence to address the legality of the use of nuclear weapons, even in view of the health effects of their use. ${ }^{18}$

\footnotetext{
12 Id. at $12-13$.

${ }^{13}$ Legality of the Use by a State of Nuclear Weapons in Armed Conflict, Advisory Opinion, 1996, I.C.J. 68 (July 8).

${ }^{14}$ Australia, Azerbaijan, Colombia, Costa Rica, Democratic People's Republic of Korea, Finland, France, Germany, India, Ireland, Islamic Republic of Iran, Italy, Japan, Kazakhstan, Lithuania, Malaysia, Mexico, Nauru, Netherlands, New Zealand, Norway, Papua New Guinea, Philippines, Republic of Moldova, Russian Federation, Rwanda, Samoa, Saudi Arabia, Solomon Islands, Sri Lanka, Sweden, Uganda, Ukraine, United Kingdom of Great Britain and Northern Ireland, and United States of America submitted written statements.

${ }^{15}$ Costa Rica, France, India, Malaysia, Nauru, Russian Federation, Solomon Islands, United Kingdom of Great Britain and Northern Ireland, and United States of America submitted written comments on their written statements.

${ }^{16}$ Legality of the Use by a State of Nuclear Weapons in Armed Conflict, Advisory Opinion, 1996, I.C.J. 73 (July 8).

${ }^{17}$ Id. at 78 .

${ }^{18} / d$. at 79.
} 
The Court's rejection of international organizations having unlimited powers to request legal opinion supports the ideal type of the Prince. Only sovereign states have powers to address all international legal issues.

\section{Legality of the Use by a State of NuClear Weapons in ARMed Conflict}

The Court addressed the issue of nuclear weapons again in 1996 when the United Nations General Assembly ("General Assembly") passed resolution 49/75 asking the Court: "Is the threat or use of nuclear weapons in any circumstance permitted under international law?"19 Nearly 30 states filed written statements. ${ }^{20}$ The Court concluded that it had both competence and jurisdiction ${ }^{21}$ and rejected the appeal by the United States, the United Kingdom, France, Finland, Netherlands and Germany to use its discretionary power to decline rendering an opinion. $^{22}$ The Court held unambiguously that it "may give an advisory opinion on any legal question, abstract or otherwise." ${ }^{23}$

The Court rejected the General Assembly's use of the word "permitted." The Court explained that international law is based on the principles of sovereignty and consent, and therefore, states "are free to threaten or use nuclear weapons unless it can be shown that they are bound not to do so by reference to a prohibition in either treaty law or customary law." ${ }^{24}$

The Court then addressed the conventional sources of law supporting the illegality of the use of nuclear weapons, including: (1) the right to life guaranteed in Article 6 of the International Covenant on Civil and Political Rights, ${ }^{25}$ (2) Article II of the Convention of 9 December 1948 on

${ }^{19}$ Id. at 6.

${ }^{20}$ Bosnia and Herzegovina, Burundi, Democratic People's Republic of Korea, Ecuador, Egypt, Finland, France, Germany, India, Ireland, Islamic Republic of Iran, Italy, Japan, Lesotho, Malaysia, Marshall Islands, Mexico, Nauru, Netherlands, New Zealand, Qatar, Russian Federation, Samoa, San Marino, Solomon Islands, Sweden, United Kingdom of Great Britain and Northern Ireland, and United States of America filed written statements. Use of Nuclear Weapons, Advisory Opinion, I.C.J. Reports, 1996, p. 10 १ 5.

${ }^{21}$ Legality of the Use by a State of Nuclear Weapons in Armed Conflict, Advisory Opinion, 1996, I.C.J. 18 (July 8).

${ }^{22}$ Id. at 24. See also United States of America, Written Statement, pp. 1-2; United Kingdom, Written Statement, pp. 9-20, ๆๆ 2.23- 2.45; France, Written Statement, pp. 13-20, ๆๆ 5-9; Finland, Written Statement, pp. 1-2; Netherlands, Written Statement, p. 3, ๆๆ 6-13; Germany, Written Statement, pp. 3-6, ๆ 2 (b).

${ }^{23}$ Legality of the Use by a State of Nuclear Weapons in Armed Conflict, Advisory Opinion, 1996, I.C.J. 24 (July 8).

${ }^{24}$ Id. at 28.

${ }^{25}$ Id. at 30 . 
the Prevention and Punishment of the Crime of Genocide, ${ }^{26}$ (3) norms relating to protecting the environment, as stated in the Article 35 of the Additional Protocol 1 of 1977 to the Geneva Conventions of 1949 (prohibiting "methods or means of warfare which are intended, or may be expected, to cause widespread, long-term and severe damage to the natural environment") and the Convention of 18 May 1977 on the Prohibition of Military and Any Other Hostile Use of Environmental Modification Techniques (prohibiting the use of weapons which have "widespread, long-lasting and severe effects" on the environment); ${ }^{27}$ as well as the conventional treaties opposed to the general use of force, including (4) the International Covenant on Civil and Political Rights ("ICCPR") ${ }^{28}$ and (5) a number of Environmental treaties. ${ }^{29}$

First, the Court dismissed: the ICCPR guarantee of a general "right to life" as prohibiting states from using nuclear weapons. The Court reasoned that while the guarantee in the ICCPR does not cease to have effect during times of war, the illegality of conflict is determined by the laws of armed conflict and not by the terms o the ICCPR.

[W] hether a particular loss of life, through the use of a certain weapon in warfare, is to be considered arbitrary deprivation of life contrary to Article 6 of the Covenant [ICCPR], can only be decided by reference to the aw applicable to armed conflict and not deduced from the terms of the Covenant itself. ${ }^{30}$

In other words, loss of life is not contrary to Article 6 of the ICCPR unless the loss of life is the consequence of an act that contravened the terms of the applicable law of armed conflict. The Court applied the same logic to all conventional law and customary law guaranteeing life.

Second, the Court rejected environmental treaties as a source of conventional law prohibiting states from using nuclear weapons. Some environmental treaties explicitly address environmental protection during armed conflict (for example, General Assembly Resolution $47 / 37$ of 25 November 1992 affirms that environmental consideration is an element to be taken into account when implementing the principles of law governing armed conflict, stating "destruction of the environment, not justified by military necessity and carried out wantonly, is clearly contrary to existing international law"), ${ }^{31}$ but because not all states have become parties to certain environmental treaties, these treaties do not generally prohibit states from using nuclear weapons during armed conflict.

${ }^{26} / d$. at 32.

${ }^{27} / d$. at 34.

${ }^{28}$ Id. at 30.

${ }^{29} / d$. at 34.

${ }^{30} / d$. at 32.

${ }^{31} / d$. at 34-5. 
Third, the Court rejected the argument that the United Nations Charter (the "Charter") prohibited the use of nuclear weapons. ${ }^{32}$ The Court held that states have the right to selfdefense and reprisal-even with nuclear weapons-as long as that self-defense and reprisal conform to the proportionality rule (that is, that the response to an attack is proportionate to the attack itself). ${ }^{33}$

Finally, the Court dismissed customary law as prohibiting states from using nuclear weapons, despite a General Assembly resolution proclaiming their illegality.

...the first of the resolutions of the General Assembly expressly proclaiming the illegality of the use of nuclear weapons, resolution 1653 (XVI) of 24 November 1961 (mentioned in subsequent resolutions), after referring to certain international declarations and binding agreements, from the Declaration of St. Petersburg of 1868 to the Geneva Protocol of 1925, proceeded to qualify the legal nature of nuclear weapons, determine their effects, and apply general rules of customary international law to nuclear weapons in particular. That application by the General Assembly of general rules of customary law to the particular case of nuclear weapons indicates that, in its [the Court's] view, there was no specific rule of customary law which prohibited the use of nuclear weapons; if such a rule had existed, the General Assembly could simply have referred to it and would not have needed to undertake such an exercise of legal qualification. ${ }^{34}$

The Court held that given the current state of international law, the Court could not conclude definitively whether the use of nuclear weapons by a state is legal in "an extreme circumstance of self-defence in which the state's very survival would be at stake." ${ }^{35}$ However, the Court emphasized that there are certain fundamental rules of humanitarian law the must be observed by all states-regardless of whether the states have ratified the conventions that contain them-because they constitute "intransgressible principles of international customary law." ${ }^{36}$ Despite a general consensus among states that humanitarian law, as part of jus cogens, applies to the use of nuclear weapons, there was no consensus among states about whether this application prohibited the use of nuclear weapons. ${ }^{37}$

The Court's analysis in this case an acceptance that the state can use whatever means necessary to defend itself. However, there are two sources of tension between the Prince and

\footnotetext{
32 Id. at 38.

${ }^{33}$ Id. at $43-4$.

${ }^{34}$ Id. at 33.

${ }^{35}$ Id. at 41 .

${ }^{36}$ Id. at 35.

${ }^{37}$ Id. at 39-40.
} 
the Citizen in this case. First, although the Court accepted the state's right to do what is necessary to defend itself, including using nuclear weapons, the Court held that states are still bound by certain fundamental principles of humanitarian law even when those states have not ratified international humanitarian conventions or conventions directly addressing the use or threat of use of nuclear weapons. ${ }^{38}$ Second, despite the requests by a number of powerful states for the Court to use its discretionary power to decline the case, the Court chose to provide an advisory opinion. By providing this opinion, the Court has supported the Citizen version of sovereignty insofar as the Court's action supports the cause of international legal proceduralism. In other words, even though the strict holding is that the current state of international law does not generally prohibit the use of nuclear weapons by states, the fact that there is a holding suggests that even questions that go to the heart of sovereignty are subject to international law.

\section{Fisheries Jurisdiction CASE (Spain V. CANADA)}

In 1998, the Court rendered its decision in the fishing dispute between Spain and Canada arising out of an amendment to the Canadian Coastal Fisheries Protection Act. Spain requested the Court to declare, among other things, that Canada's legislation claiming jurisdiction over ships flying foreign flags on the high seas was contrary to international law and that Canada must refrain from repeating the incident when it boarded the Spanish ship Estai and brought the ship and its crew to Newfoundland. ${ }^{39}$ Canada claimed that the I.C.J. did not have jurisdiction to hear the case. ${ }^{40}$

In May 1994, Canada passed legislation (Parliament Bill C-29 amending the Coastal Fisheries Protection Act) extending protection of an area known as the Regulatory Area of the Northwest Atlantic Organization ("NAFO"). The bill authorized certain Canadian "protection officers" to ensure compliance with the new legislation by boarding and inspecting any vessel within the NAFO area and, with a warrant, search any fishing vessel and arrest the person commanding the vessel, among other things. ${ }^{41}$

\footnotetext{
${ }^{38}$ See, e.g., Treaty of Tiatelolco of 14 February 1967 for the Prohibition of Nuclear Weapons in Latin America, the Treaty of Rarotonga of 6 August 1985 establishing a South Pacific Nuclear Free Zone, the Antarctic Treaty of 1959, prohibiting the deployment of nuclear weapons in the Antarctic or the 1963 Partial Test-Ban Treaty or the Treaty on the Non-Proliferation of Nuclear Weapons, limiting the use of nuclear weapons.

${ }^{39}$ Fisheries Jurisdiction Case, (Spain v. Can.), 19989 (Dec. 4).

${ }^{40}$ Id. at 7.

${ }^{41} / d$. at $11-12$.
} 
Two days before Canada passed the new legislation, Canada deposited with the UN SecretaryGeneral a declaration giving notice that Canada was terminating its acceptance of compulsory jurisdiction of the I.C.J. in, among other areas, disputes concerning the conservation and management of fishing vessels in the NAFO area. ${ }^{42}$

The Court held that it did not have jurisdiction to decide the case because Canada's actions fell within the limits of its declaration concerning compulsory jurisdiction of the I.C.J., despite Spain's arguments that Canada's actions were illegal under customary international law and infringed on the sovereignty of a European member state. ${ }^{43}$ The Court held:

It is for each State, in formulating its declaration, to decide upon the limits it places upon its acceptance of the jurisdiction of the Court: "This jurisdiction only exists within the limits within which it has been accepted." ... A declaration of acceptance of the compulsory jurisdiction of the Court, whether there are specified limits set to that acceptance or not, is a unilateral act of State sovereignty. ${ }^{44}$

The Court's opinion in this case supports a core value of the Prince that international law exists only with the agreement of individual sovereign states. The Court made it clear that Canada's declaration terminating compulsory I.C.J. jurisdiction for disputes concerning the conservation and management of fishing in certain areas was Canada's sovereign right. ${ }^{45}$

\section{B. THE PROTECTOR}

The office of sovereign, be it monarch or an assembly, consisteth in the end for which he was trusted with the sovereign power, namely the procuration of the safety of the people, ... But by safety here is not meant a bare preservation, but also all other contentments of life, which every man by lawful industry, without danger or hurt to the Commonwealth, shall acquire to himself. $^{46}$

The Protector justifies its authority on its ability to protect its own citizens and environment. Unlike the Prince, in which the state does not justify its supreme power but simply claims it because the state is, the Protector takes certain actions (or does not take certain actions) based on protecting its people and environment.

\footnotetext{
${ }^{42}$ Id. at $10-11$.

${ }^{43}$ Id. at 24.

${ }^{44}$ Id. at $24-25$.

${ }^{45}$ Canada gave notice that it was terminating its acceptance of compulsory jurisdiction before it changed its internal laws governing fishing in the NAFO area. In other words, Canada exercised its sovereign rights pursuant to international legal procedures.

${ }^{46}$ Thomas Hobbes, Leviathan 153 (Encyclopedia Brittanica ed.) (1992).
} 
The Protector shares many features with the Prince: both place the sovereign state above the global community of states and both put the sovereign states above international law, but the Protector is endowed with special rights only because it fulfills certain responsibilities. Hobbes creates a blueprint of this ideal type in Leviathan; or the Matter, Forme and Power of the Commonwealth, Ecclesiastical and Civil, which sets out a contract between the people and the state whereby the people grant sovereignty to the state in return for the state fulfilling certain obligations to the citizens.

This line of cases is based on the common theme that sovereignty allows the state to breach international legal obligations because the state is the sole entity with the power to protect its citizens. This conceptualization is a powerful argument for sovereignty because it appeals to the basic human desire to protect one's self from harm, but in the most recent cases discussed below, the Court has rejected protection as a legitimate reason to justify a state breaching international obligations. There is tension between this line of cases and the Prince line of cases because, one the one hand, the Court accepts that sovereignty endows states with the power to wage nuclear war to defend itself and the right to reject the jurisdiction of the I.C.J. in order to protect and manage the environment for fishing, but on the other hand, the Court rejects a state's right to build a wall to protect its citizens from an acknowledged terrorist threat and denies another state's right to reject a Soviet-era contract in order to protect the environment. There is no simple way to explain the discrepancy between the two lines of cases. The apparent logical inconsistency is not likely to be resolved by the I.C.J. or by prevailing norms of state behavior. Rather, I think, the tension between the logic in the Prince and the Protector underscores the importance of developing a functioning vocabulary to describe competing conceptualizations of sovereignty.

\section{Legal Consequences of the Construction of a Wall in the Occupied Palestinian TERRITORY}

In 2004, the Court rendered its advisory opinion on the General Assembly question concerning the legal consequences of Israel constructing a wall in the Occupied Palestinian Territory (including around East Jerusalem)? ${ }^{47}$ Over 45 parties submitted written statements. ${ }^{48}$ The General Assembly based its request for an advisory opinion largely on resolution ES-10113,

\footnotetext{
${ }^{47}$ Construction of Wall, Advisory Opinion, 2004 I.C.J. 9 (July 9).

${ }^{48}$ Guinea, Saudi Arabia, League of Arab States, Egypt, Cameroon, Russian Federation, Australia, Palestine, United Nations, Jordan, Kuwait, Lebanon, Canada, Syria, Switzerland, Israel, Yemen, United States: of America, Morocco, Indonesia, Organization of the Islamic Conference, France, Italy, Sudan, South Africa, Germany, Japan, Norway, United Kingdom, Pakistan, Czech Republic, Greece, Ireland on its own behalf, Ireland on behalf of the European Union, Cyprus, Brazil, Namibia, Malta, Malaysia, Netherlands, Cuba, Sweden, Spain, Belgium, Palau, Federated States of Micronesia, Marshall Islands, Senegal, Democratic People's Republic of Korea. Construction of Wall, Advisory Opinion, I.C.J. Reports, 2004, p. 10 १ 9.
} 
adopted by the General Assembly on 27 October 2003, which demanded Israel stop and reverse the construction of the wall in the Occupied Palestinian Territory. ${ }^{49}$

Israel argued that the Court did not have jurisdiction because the General Assembly acted ultra vires under the Charter when it requested an advisory opinion because Security Council was then actively involved in the Middle East. ${ }^{50}$ The Court, however, rejected Israel's arguments because, among other things, the General Assembly has the authority to act when the Security Council has both (1) failed to exercise its responsibility for maintaining international peace as the result of negative votes of one or more permanent members and (2) there appears to be a threat to the peace, breach of peace or act of aggression. ${ }^{51}$ In the Court's view, the construction of the wall in the Occupied Palestinian Territory met that requirement.

First, the Court stated that the Israeli settlements in the Occupied Palestinian Territory were in breach of international law. ${ }^{52}$ Pursuant to paragraph 3 of Article 6 of the Fourth Geneva Convention people living in the Occupied Territory "shall not be deprived, in an case or in any manner whatsoever, of the benefits" of the Fourth Geneva Convention. ${ }^{53}$ By constructing a wall, the Court held that Israel was in breach of several treaty obligations because the wall had destroyed certain agricultural lands and in certain areas, (such as the Qalqilya enclave) citizens were restricted in the times they can enter and exit the area. ${ }^{54}$

Second, the Court rejected Israel's argument that the construction of the wall was justified by Israel's right to self-defense, as laid out in Article 51 of the Charter. ${ }^{55}$ Article 51 recognizes the inherent right of self-defense in the case of an armed attack by one state against another state. The Court held that no such armed attack existed or was claimed to exist in the Occupied Territory. Furthermore, Israel did not claim that the attacks against its citizens were imputable to a foreign state. The Court also pointed out that Israel exercises control over the Occupied Palestinian Territory and so it cannot also claim the right to self-defense. ${ }^{56}$ The Court accepted that Israel faces many indiscriminate and deadly acts of violence against its civilian population and that Israel has the right and the duty to respond and protect the life of its citizens, but

\footnotetext{
${ }^{49}$ Construction of Wall, Advisory Opinion, 2004 I.C.J. 15 (July 9).

${ }^{50} / d$.

${ }^{51} / d$. at $18-19$.

${ }^{52}$ Id. at 52.

${ }^{53}$ Id. at 53-54.

${ }^{54}$ Id. at 57-58.

${ }^{55}$ Id. at 62.

${ }^{56} / d$.
} 
stated that any measures Israel takes to protect its citizens must conform with applicable international law. ${ }^{57}$ The Court found that Israel's construction of a wall was contrary to applicable international law. ${ }^{58}$

This case sets the bar extremely high for the Protector. Although the Court made reference to the importance that a state protect its citizens, the standard a state must meet in order to comply with international norms and conventions in this case were too high for Israel to demonstrate that building a wall in the Occupied Territory comported with those norms.

\section{Case Concerning the Gabcíkovo-Nagymaros Project (Hungary/Slovakia)}

The question before the Court in this 1997 decision was whether Hungary was entitled to suspend (and later abandon) the work on the Nagymoros Project and part of the Gabcíkovo project, which combined were part of a large barrage project on the river Danube initiated by the Budapest Treaty of 1977 between Czechoslovakia and Hungary to prevent catastrophic floods, to improve sailing quality and to produce clear electricity. Hungary argued that the suspension was justified by a "state of ecological necessity." that the state of necessity Hungary relied upon "did not constitute a reason for the suspension of a treaty obligation recognized by the law of treaties." 60

The disagreement between the two states was straightforward and the Court simply applied the standards necessary for showing a state of necessity as defined by Article 33 of the International Law Commission. In order to meet that standard, Hungary must demonstrate that (1) there was an essential interest of the state which conflicts with its international obligations, (2) the relevant interest was threatened by "grave and imminent peril" and (3) the act being questioned was the "only means" the state had of safeguarding the essential state interest. ${ }^{61}$

Although the Court acknowledged that safeguarding ecological interests was an essential interest of all states, the danger posed by the barrage of the Danube was not imminent in 1989 when Hungary suspended its work on the project. ${ }^{62}$

\footnotetext{
${ }^{57}$ Id. at 63.

${ }^{58} / d$.

${ }^{59}$ The Gabcíkovo-Nagymaros Project, (Hung./Slovk.), 1997 I.C.J. 32 (Sept. 25).

${ }^{60}$ Id. at 34.

${ }^{61}$ ld. at 37-38.

${ }^{62}$ Id. at 41.
} 
This case is significant in terms of defining the Protector because the Court directly addresses weighing environmental damage and complying with treaty obligations. What is intriguing in this decision is that the Court suggests that environmental concerns transcend state borders, which could make it a very difficult precedent in the future for states who want to claim a state of necessity on the basis of ecological concerns. It seems that the Court may be indicating that because environmental damage does not respect state borders, one state alone cannot claim a state of necessity.

\section{The Citizen}

A society of states (or international society) exists when a group of states, conscious of certain common interests and common values, form a society in the sense that they conceive of themselves to be bound by a common set of rules in their relations with one another and share in the workings of common institutions. ${ }^{63}$

At the core of the Citizen is the idea that the state is bound by the norms and rules of a larger community of states and people within the state's own borders. The state as Citizen is antithetical to both an anarchical and hierarchical international structure. That is to say, sovereignty that relies on citizenship in a society of states does not allow for any state-even the most powerful-to reject international norms. States are bound by norms of the larger international community of fellow states as well as obligations to citizens living within states' own borders. Sovereignty, that is the ultimate power to decide, does not reside in the state government structure, but rather is dispersed in the people as a whole (and their collective right to elect their officials and, in the extreme, to revolt) and the community of states who collectively recognize a state as a member of the international community (and hence a "sovereign state") or not depending on whether a state complies generally with the norms and responsibilities generally agreed upon by the international community of sovereign states. Deudney describes such a political structure as "negarchy" because the structure is defined by what it negates rather than what it allows. In other words, a negarchy is a system that prevents certain actions by binding actors.

Negarchy is the arrangement of institutions needed to prevent simultaneously the emergence of hierarchy and anarchy. In a workable negarchy, the particular configurations of negatives vary with the relative strengths of multiple threats, but the antithesis to hierarchy and anarchy remains constant. Understood this way, negarchy is a third-and liberal-structural principle of political order, along with hierarchy and anarchy. ${ }^{64}$

\footnotetext{
${ }^{63}$ Hedley Bull, The Anarchical Society 13 (1977).

${ }^{64}$ Daniel Deudney, State Sovereignty as Social Construct 205 (Thomas J. Biersteker and Cynthia Weber eds.) (1996).
} 
Deudney argues that the early American history (between the establishment of the Union beginning in 1781 and the American Civil Was ending in 1865) provides a robust example of such a negarchical system. ${ }^{65}$ The Philadelphian system, with its "American emphasis on laws and procedures to resolve conflicts and allocate goods," relied on the practice of legal procedures to moderate anarchical dynamics. ${ }^{66}$ Even in cases of territorial disputes, an area of "hard politics" notorious for upsetting even the most liberal structures, Deudney argues that during the negarchical period of American history, legal proceduralism took precedence of violence as a method for resolving conflicts. One case he describes concerned a conflict over territory in northeastern Pennsylvania between Connecticut and Pennsylvania resulting from overlapping charter grants. Although there had been some violent skirmishes between the two states, both Pennsylvania and Connecticut accepted an ad hoc legal arbitration set up in New Jersey.

Since the 1990's, the majority of the cases the Court has decided underscore the developing importance of states binding themselves in a nascent negarchical structure. The cases in this line is varied but they share two central themes (1) the court asserts its legal authority in defining state responsibilities and (2) sovereign states accept legal procedures as a means of resolving conflicts. Furthermore, in this conceptualization of sovereignty there are no absolutes, but rather there is a sliding scale of "more or less" sovereign. Sovereign states bind themselves so as to avoid the potential violent consequences of unbridled power. Sovereignty is the ultimate power to decide, but the scope of decisions that can be made is limited. The Court's reasoning in the Nuclear Weapons cases-cases that on one level strongly support the sovereignty as Prince-illustrates this scope limitation. There is nothing in current international law to preclude a sovereign state from using nuclear weapons in proportionate self-defense, but the sovereign state is bound to not use nuclear weapons offensively or as a disproportionate response to an attack. Of course, the skeptic may argue that there really is no Citizen conceptualization because if a state wanted to use nuclear weapons offensively, there is nothing that could prevent that state from doing so. To that argument, I can only respond that the same can be said about any state that prohibits its citizens from murdering each other. If one citizen wants to murder another, he or she most certainly can and the state can do nothing to prevent the murder. The mere fact that murder happens, does not mean that there is no law against citizens killing each other. I would argue that the reasoning applies to the line of cases that make up the Citizen. The fact that states can and do act in ways contrary to the general norms does not demonstrate that sovereign states have not bound themselves, any more so than the fact that citizens occasionally kill each other demonstrates that there is no agreed-upon prohibition of murder. The Citizen is not meant to predict the future of state

\footnotetext{
${ }^{65}$ Id. at 191.

${ }^{66}$ Id. at 208.
} 
interaction or describe all of sovereignty, but rather it is an addition to a working vocabulary of state sovereignty.

\section{Case Concerning the Application of the Convention on the Prevention and Punishment of the Crime of Genocide (Bosnia Herzegovina v. Serbia and Montenegro)}

In 2007, the Court rendered its decision in the Case Concerning the Application of the Convention on the Prevention and Punishment of the Crime of Genocide. Bosnia and Herzegovina requested the Court to adjudge and declare, among other things, that the Federal Republic of Yugoslavia (the "FRY") had violated the Convention on the Prevention and Punishment of the Crime of Genocide (the "Genocide Convention") by destroying and attempting to destroy in whole national, ethnical or religious groups within the territory of Bosnia and Herzegovina, in particular the Muslim population. ${ }^{67}$ The FRY contended that the acts alleged were not committed. ${ }^{68}$

First, the Court confirmed that it did have jurisdiction based on Article XI of the Genocide Convention. ${ }^{69}$ Then the Court addressed the problem of the duality of its responsibility that international law is concerned with the actions of sovereign states and does not punish individuals. The Court re-stated the famous phrase from the Nuremberg Judgment that "[c]rimes against international law are committed by men, not abstract entities..."

Second, the Court affirmed that both Bosnia Herzegovina and Serbia and Montenegro are bound by their obligation under the Genocide Convention not to commit "through their organs or persons who conduct is attributable to them" genocide or any of the other acts proscribed by the Genocide Convention. ${ }^{71}$

Third, the Court concluded that there had been massive killings in detention camps and other areas throughout Bosnia and Herzegovina and those massacres constituted genocide. ${ }^{72}$

${ }^{67}$ Application of the Convention on the Prevention and Punishment of the Crime of Genocide (Bosn. \& Herz. v. Serb. \& Mont.), 2007 I.C.J. 23 (Feb. 26).

${ }^{68}$ Id. at 24.

${ }^{69}$ Id. at 55.

${ }^{70}$ Id. at 65. See also, Judgment of the International Military Tribunal, Trial of the Major War Criminals, 1947, Official Documents, Vol. 1, p. 223.

${ }^{71}$ Application of the Convention on the Prevention and Punishment of the Crime of Genocide (Bosn. \& Herz. v. Serb. \& Mont.), 2007 I.C.J. 67 (Feb. 26).

${ }^{72}$ /d. at 106. 
Having established that genocide had been committed, the Court then addressed the question of whether the Respondent State of Serbia and Montenegro could be held responsible. The Court had to decide whether genocide and the other acts could be attributed to the Respondent by ascertaining whether any person or organ whose acts can be attributed to the Respondent committed the relevant acts. ${ }^{73}$

Under international law, a state is responsible for any act committed by its state organ. ${ }^{74} \mathrm{~A}$ state can also be held responsible for the conduct or persons, or groups of persons, who do not have the legal status of state organs if they are under the "strict control" of the state in question. ${ }^{75}$ The standard for determining "strict control" requires the Court to find that such persons or groups are "wholly dependent" on the state. ${ }^{76}$ Being "wholly dependent" requires a finding that the state gave specific instructions-and not merely general instructions-to those carrying out the violations. ${ }^{77}$

Applying these standards to the evidence of massacres at Srebrenica, the Court found that it was not established that FRY was responsible for the actions of those who committed the massacres. ${ }^{78}$ However, the Court concluded that FRY violated its obligation to prevent the Srebrenica genocide and had failed to punish those responsible. ${ }^{79}$

This decision underscores the idea of the state as a Citizen of a society of states because the Court applied a clear standard of behavior and applied those standards to a concrete case. The decision demonstrates that international norms require states to comply with international laws within their own borders. States must comply with humanitarian law even within its own borders. While the standard the Court applied to determine state attribution has left some observers frustrated, that standard does not alter the underlying political and legal decision that states are bound by humanitarian law in dealing with their own citizens, even in times of conflict.

\footnotetext{
${ }^{73}$ Id. at 136.

${ }^{74}$ Id. at 138.

${ }^{75}$ Id. at 140 .

${ }^{76} / d$.

${ }^{77}$ Id. at 143.

${ }^{78}$ Id. at 148 .

${ }^{79}$ Id. at 161 .
} 


\section{LAGRAnd CASE (Germany V. United States of AMERICA)}

This 2001 case concerns two German nationals who had been put to death in Arizona after having been found guilty of murder. The German nationals were brothers, Karl and Walter Bernhard LaGrand, who had been found guilty of killing a man and severely injuring a woman during the course of robbing a bank in Arizona. The brothers had been born in Germany, but although they had lived in the United States since they were very young, they had never acquired United States citizenship. As foreign nationals, they were consequently entitled to contact their consulate under Article 36 of the Vienna Convention on Consular Relations (the "Vienna Convention").

Germany asked the Court to declare, among other things, that (1) the United States violated the Vienna Convention by not notifying the German consulate of the LaGrand brothers' arrest, (2) certain U.S. legal rules make it impossible for foreign states to raise lack of consular notification under U.S. law and (3) the United States violated its international legal obligations by failing to take all possible measure to ensure that the LaGrand brothers were not executed pending a final decision in the I.C.J. case concerning the brothers. The United States apologized to Germany for not notifying Germany and instituted certain precautionary measures to prevent a similar recurrence, but asked the Court otherwise to dismiss Germany's claims. ${ }^{80}$

The case arose in the first place because there was some confusion over the nationality of the LaGrand brothers from the time they were arrested. ${ }^{81}$ Apparently, the brothers had been adopted by an American and "had the demeanor and speech of Americans rather than Germans." ${ }^{82}$ The United States argued that not only did the brothers not identify themselves as Germans, but also that the brothers themselves were unaware that they were not U.S. nationals. ${ }^{83}$ The brothers' court appointed counsel did not raise non-compliance with the Vienna Convention in the defense and did not contact the German consular authorities. ${ }^{84}$ Even during the lengthy period of appeals after conviction, no one notified German consular authorities and the brothers' attorneys did not raise the issue of failing to notify German consular authorities as required by the Vienna Convention. ${ }^{85}$ It was not until the brothers' counsel had filed writs of habeas corpus that the Vienna Convention issue of consular

\footnotetext{
${ }^{80}$ The LaGrand Case, (F.R.G. v. U.S.), 2001 I.C.J. 11 (June 27).

${ }^{81}$ Id. at 14 .

${ }^{82}$ Id. at 13.

${ }^{83} / d$.

${ }^{84}$ Id. at 14.

${ }^{85} / d$. at 15.
} 
notification was raised. The United States District Court for the District of Arizona rejected the issue of consular notification on the basis of the "procedural default rule" which provides that issues cannot be raised in federal courts of appeal unless they have first been raised in state courts. ${ }^{86}$

On 21 December 1998, U.S. authorities formally notified the LaGrand brothers of their right to consular access. On 15 January 1999, the Arizona Supreme Court decided that Karl LaGrand would be executed on 24 February 1999 and Walter LaGrand would be executed on 3 March 1999. Germany claimed to have learned of the execution dates on 19 January $1999 .^{87}$

On 19 January 1999, Germany launched proceedings in the United States Supreme Court against both the United States and the Governor of Arizona seeking, among other things, to enforce compliance of an I.C.J. Order requiring provisional measures postponing the brothers' executions pending a final decision in the I.C.J. case. The United States Solicitor General argued that an I.C.J. order requiring provisional measures is not binding and does not provide a basis for relief. ${ }^{88}$ The U.S. Supreme Court held that it lacked jurisdiction with respect to Germany's complaint against Arizona due to the eleventh amendment of the U.S. constitution, which prohibits federal courts from hearing lawsuits of foreign states against a U.S. state. Regarding Germany's claim against the United States, the U.S. Supreme Court held the doctrine of procedural default was not incompatible with the Vienna Convention and that even if procedural default did conflict with the Vienna Convention it had been overruled by later federal law-the Antiterrorism and Effective Death Penalty Act of 1996, which explicitly legislated the doctrine of procedural default.

The United States Department of State conveyed the I.C.J.'s order to the Governor of Arizona without comment. The Arizona clemency board recommended a stay of execution to the governor on the basis of the I.C.J. provisional measure. The governor of Arizona ignored the recommendation and both brothers were executed.

The I.C.J. held in Germany's favor that (1) the United States had violated its obligations under paragraph $1(b)$ of the Vienna Convention when it failed to inform Germany's consular authorities that it had detained German nationals; ${ }^{89}$ (2) the procedural default rule effectively prevented Germany from challenging the LaGrands' convictions and sentences under United States constitutional grounds, which prevented "full effect [from being] given to the purposes

\footnotetext{
${ }^{86} / d$.

${ }^{87}$ Id. at 16.

${ }^{88}$ Id. at 17.

${ }^{89}$ Id. at 32.
} 
for which the rights accorded under this article [Article 36 of the Vienna Convention] are intended, ${ }^{\prime \prime}{ }^{90}$ and (3) the I.C.J.'s power to indicate provisional measures is binding. ${ }^{91}$

While the Court's decision favored Germany, the Court noted that the United States had (1) acknowledged that it had not complied with its obligation to give consular notification, (2) apologized to Germany, and (3) the United States had provided the Court with information on a program it was carrying out to ensure that both state and federal authorities comply with the United States' obligations under Article 36 of the Vienna Convention. ${ }^{92}$

This case is significant not only because it demonstrates the necessity that states comply with international norms (and the United States took efforts to prevent a future breach), but also because this case stands for the proposition that a state's internal laws must comply with its external obligations. The Court held that the procedural default prevented the United States from complying with its obligations under the Vienna Convention. In other words, this case demonstrates states binding themselves in their internal and external actions.

\section{Case Concerning Armed Activities on the Territory of the Congo (Democratic REPUBLIC OF CONGO V. UGANDA)}

This 2005 case concerns whether Uganda violated its obligations under customary and international law, including (1) the non-use of force and the prohibition of aggression, (2) the obligation to settle international disputes peacefully, (3) to respect sovereignty and the right of people to self-determination and (4) the principle of non-intervention. ${ }^{93}$ The Court acknowledged the "tragic situation which has long prevailed in the Great Lakes region" and noted that the local population had long suffered because of factional conflictions between Democratic Republic of Congo ("DRC") and armed groups from neighboring states (i.e., The Republic of Uganda). ${ }^{94}$

\footnotetext{
${ }^{90} / d$. at 35-36.

${ }^{91}$ Id. at 41.

92 "The Court considers that the commitment expressed by the United State to ensure implementation of the specific measures adopted in performance of its obligations under Article 36, paragraph 1(b), must be regarded as meeting Germany's request for a general assurance of non-repetition." The LaGrand Case, (F.R.G. v. U.S.), 2001 I.C.J. 123 (June 27).

${ }^{93}$ Armed Activities in Congo (Dem. Rep. Congo v. Uganda), 2005 I.C.J. 26 (Dec. 19).

${ }^{94}$ Id. at 25.
} 
Uganda argued that the DRC consented to the actions of its troops in the DRC until 11 September 1998 and that after that date Uganda was acting in self-defense. ${ }^{95}$ In general, Uganda did not argue that the events the DRC alleged did not occur, but rather that the Uganda's military action was legal.

The Court found otherwise. The Court held that Uganda had violated international law and was obligated to make reparations to the DRC. The Court's holding is clear: armed conflict does not excuse states from complying with international humanitarian law. This case stands for the proposition that states must comply with international customs and treaties, even in times of armed conflict and supports the line of cases establishing a basis of states as citizens who are bound by certain norms in international relations.

\section{CASe Concerning Territorial and Maritime Dispute between Nicaragua AND Honduras in the CaribBean SEa (Nicaragua v. Honduras)}

This 2007 case dates back to a colonial dispute in the early 1800s. Both Nicaragua and Honduras had been Spanish colonies and became independent in 1821. At that time Nicaragua and Honduras-along with Guatemala, El Salvador and Costa Rica-formed the Federal Republic of Central America. In 1838, both Nicaragua and Honduras seceded from the Federation, maintaining the territory they had before they had joined the Federation. In 1850, the Republic of Nicaragua and Spain signed a treaty in which Spain recognized Nicaragua as "free, sovereign and independent" with "all its territories that now belong to it from sea to sea, or that will later belong to it." ${ }^{\prime \prime 6}$ In 1866, Honduras and Spain signed a similar treaty in which Spain recognized Honduras as a "free, sovereign and independent state, which comprises the entire territory that was the province of that name during the period of Spanish domination, this territory being bounded in the East, Southeast and South by the Republic of Nicaragua." ${ }^{\prime 97}$ In 1869, Nicaragua and Honduras attempted to delineate their boundary by signing the FerrerMedina Treaty and the Ferrer-Uriarte Treaty in 1870, but neither treaty entered into force. ${ }^{98}$ In 1894, Nicaragua and Honduras successfully concluded the Gámez-Bonilla Treaty, which stated that according to the principle of uti possidetis juris, each state "is the owner of the territory which at the date of independence constituted respectively, the provinces of Honduras and

\footnotetext{
${ }^{95}$ Id. at 41-53.

${ }^{96}$ Case Concerning Territorial and Maritime Dispute between Nicaragua and Honduras (Nicar. and Hond.), 2007 I.C.J. 14-15 (Oct. 8).

${ }^{97}$ Id. at 15.

${ }^{98} / d$.
} 
Nicaragua." ${ }^{99}$ The treaty also set out a commission whose duty it was to settle all pending boundary differences in a "friendly manner." The committee met for four years but was unable to determine all boundaries. Pursuant to Article III of the Gámez-Bonilla Treaty, Nicaragua and Honduras submitted their dispute over the remaining boundaries to the King of Spain, as sole arbitrator. King Alfonso XIII of Spain made his decision in 1906. ${ }^{100}$ Nicaragua then challenged the validity of the king's arbitral award and, after several failed attempts to settle the dispute (including an ad hoc committee of the Organization of American States who addressed the issue), Nicaragua and Honduras agreed to submit the dispute to the I.C.J. ${ }^{101}$

The Court's analysis of the boundary dispute began first with the principle that maritime rights are determined by the coastal state's sovereignty over the land, which means sovereignty over certain islands would determine the maritime boundary. ${ }^{102}$ In order to determine which state had sovereignty over the disputed islands, the court invoked uti possidetis juris, the Court must consider which colony Spain had intended to have control over the islands in question and which colony actually had effective control. ${ }^{103}$

[A] claim to sovereignty based upon some particular act or title such as a treaty of cession but merely upon a continued display of authority, involves two elements each of which must be shown to exist: the intention and will to act as sovereign, and some actual exercise or display of such authority. ${ }^{104}$

Because the islands in question are uninhabited (or not permanently inhabited), the Court found it difficult to determine effective control, and so turned to the question of whether there was a pattern of displaying sovereign authority, even if those displays were modest. ${ }^{105}$ The Court reviewed a number of issue areas to determine displays of sovereignty, including whether a state (1) applied and enforced criminal and civil law, ${ }^{106}$ (2) regulated immigration, ${ }^{107}$

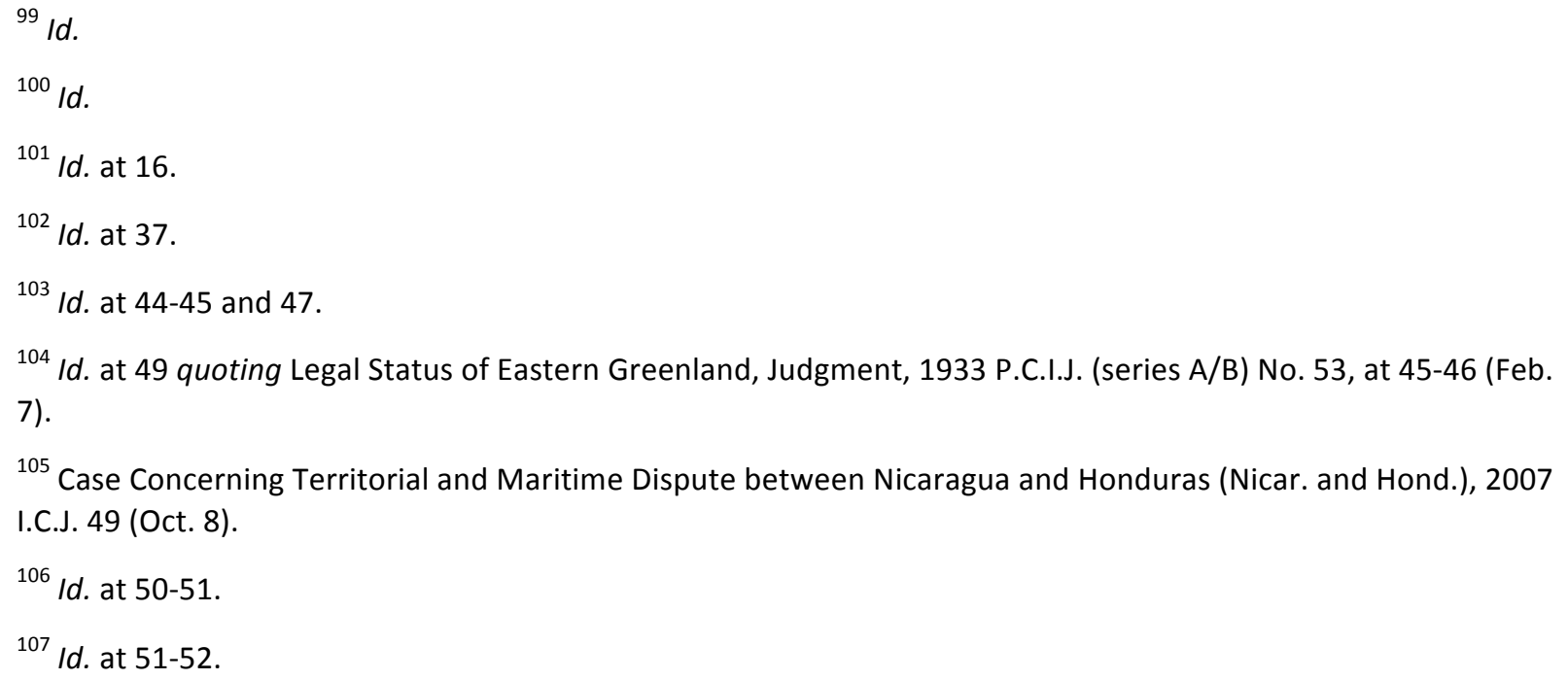


(3) regulated fishing activities, ${ }^{108}$ (4) performed naval patrols, ${ }^{109}$ and (5) performed public works. ${ }^{110}$

Having reviewed all the evidence, the Court concluded that Honduras had sovereignty over the islands in question based on its overall pattern of conduct after independence from Spain. ${ }^{111}$

The Court's decision in this case supports the Citizen line of cases on two levels for analysis: first, as an example of sovereign states binding themselves to legal procedures and second, as a source of a list of what the international community accepts as markers of sovereignty.

By jointly submitting this case to the I.C.J., Nicaragua and Honduras demonstrated the strength of legal proceduralism as a norm in international relations today. This case is strikingly similar to the example of negarchy Deudney described in which Pennsylvania and Connecticut submitted a territorial dispute stemming from competing colonial charters to an arbitral tribunal in Delaware, Honduras and Nicaragua jointly submitted this case stemming from unclear colonial treaties to the I.C.J. In both cases, armed conflict was rejected in favor of legal procedures as a method of settling territorial disputes.

Second, the Court provided a list of factors indicating what constitutes sovereignty over certain territory. This list shows a connection between norms in the international community of states and the internal organization of a state. In order to successfully claim sovereignty over a region, a state must demonstrate that it is conforming to internationally-agreed upon norms.

CONCLUSION

There is a lot of work to be done to create a working vocabulary of state sovereignty. By analyzing international legal discourse at the I.C.J., it will be possible to understand how the Court (and states themselves) uses the term sovereignty. A taxonomy of sovereignty may be a worthwhile enterprise on its own, but I would like it to be a starting point for addressing other questions concerning sovereignty, including:

- Is there a connection between the arguments concerning state sovereignty and the larger international political context? (In other words, during the post-war period of bipolar political structure, was sovereignty discussed differently than during the brief period of American hegemony or during the current fluid multi-polar political period?)

- Is there a relationship between the state type and the way a state discusses sovereignty? (Stated differently, do dominant states tend to present sovereignty in similar ways

\footnotetext{
${ }^{108}$ /d. at 52-54.

${ }^{109} / d$. at 54-55.

${ }^{110} / d$. at 55-56.

${ }^{111} / d$.
} 
despite ideological differences? Do smaller, less dominant states share similarities in their views of sovereignty?)

- How closely does the international legal discussion concerning state sovereignty track the Westphalian "ideal type" of the sovereign state?

While there is no clear end in sight for the tension between the Prince and the Citizen (or between Schmitt and Kelsen) that Koskenniemi has so eloquently describes in his work, I hope that this paper serves as a starting point for creating a working vocabulary of state sovereignty and opens the conversation between international law and international relations about what it means to be a sovereign state. 